\title{
Leptin signaling molecular actions and drug target in hepatocellular carcinoma
}

This article was published in the following Dove Press journal:

Drug Design, Development and Therapy

14 November 2014

Number of times this article has been viewed

\author{
Nan Jiangl,* \\ Rongtong Sun ${ }^{2, *}$ \\ Qing Sun ${ }^{3}$
}

'Shandong University School of Medicine, Jinan, Shandong Province, People's Republic of China; ${ }^{2}$ Weihai Municipal Hospital, Weihai, Shandong Province, People's Republic of China; ${ }^{3}$ Department of Pathology, QianFoShan Hospital Affiliated to Shandong University, Jinan, Shandong Province, People's Republic of China

*These authors contributed equally to this work
Correspondence: Qing Sun Department of Pathology, QianFoShan Hospital Affiliated to Shandong University, Jinan 2500 I4, Shandong Province, People's Republic of China Tel +8653189268155

Fax +86 53I 82963647

Email qingsun68@gmail.com
Abstract: Previous reports indicate that over 13 different tumors, including hepatocellular carcinoma (HCC), are related to obesity. Obesity-associated inflammatory, metabolic, and endocrine mediators, as well as the functioning of the gut microbiota, are suspected to contribute to tumorigenesis. In obese people, proinflammatory cytokines/chemokines including tumor necrosis factor-alpha, interleukin (IL)-1 and IL-6, insulin and insulin-like growth factors, adipokines, plasminogen activator inhibitor-1, adiponectin, and leptin are found to play crucial roles in the initiation and development of cancer. The cytokines induced by leptin in adipose tissue or tumor cells have been intensely studied. Leptin-induced signaling pathways are critical for biological functions such as adiposity, energy balance, endocrine function, immune reaction, and angiogenesis as well as oncogenesis. Leptin is an activator of cell proliferation and anti-apoptosis in several cell types, and an inducer of cancer stem cells; its critical roles in tumorigenesis are based on its oncogenic, mitogenic, proinflammatory, and pro-angiogenic actions. This review provides an update of the pathological effects of leptin signaling with special emphasis on potential molecular mechanisms and therapeutic targeting, which could potentially be used in future clinical settings. In addition, leptin-induced angiogenic ability and molecular mechanisms in HCC are discussed. The stringent binding affinity of leptin and its receptor Ob-R, as well as the highly upregulated expression of both leptin and Ob-R in cancer cells compared to normal cells, makes leptin an ideal drug target for the prevention and treatment of HCC, especially in obese patients.

Keywords: hepatocellular carcinoma, leptin, leptin antagonist, leptin signaling, tumor angiogenesis, drug target

\section{Introduction}

It has been reported that over 400 million people are obese worldwide, and the number is projected to reach 700 million by $2015 .{ }^{1}$ According to the reports from the International Association for the Study of Obesity, approximately one-fourth of European men and women are obese and approximately one-half of European men and one-third of European women are overweight. ${ }^{2}$ In the United States, where adult obesity is $30 \%-35 \%$, the obesity epidemic also poses threats to public health. ${ }^{3-6}$ The escalation of obesity and overweight has become a global problem in the past decade. Accumulating evidence indicates that the obese state shares some characteristics with chronic low-grade inflammation, which deliberates various diseases, particularly cardiovascular disease, ${ }^{7,8}$ chronic kidney disease, ${ }^{9-11}$ dyslipidemia, ${ }^{12}$ hypertension, ${ }^{13,14}$ liver disease, ${ }^{15-17}$ type 2 diabetes,${ }^{18}$ as well as a number of tumors. ${ }^{19-21}$ Many tumors, including gynecologic tumors (breast, ovarian, cervical, uterine cancer), digestive system tumors (esophageal, stomach, colon or rectal, liver, gall bladder, pancreatic), and hematologic tumors (multiple myeloma and non-Hodgkin lymphoma), as well as others, such as kidney and glioma, are found to be correlated with obesity. ${ }^{19,20,22-24}$ 
It is estimated that being overweight or obese contributes to $20 \%$ of cancer deaths in the United States. ${ }^{25}$

Although obesity has been considered as an increased risk for many cancers, the molecular mechanisms by which obesity affects cancer incidence is still unclear. Obesity-associated inflammatory, metabolic, and endocrine mediators, as well as the functioning of the gut microbiota, are suspected to contribute to tumorigenesis. Among obese people, proinflammatory cytokines/chemokines including tumor necrosis factor-alpha (TNF- $\alpha$ ), interleukin (IL)-1, IL-6, insulin and insulin-like growth factors (IGFs), adipokines, plasminogen activator inhibitor-1, adiponectin, and leptin are found to play a crucial role in the initiation and development of cancer. ${ }^{26-30}$ The gut microbiota, including altered microbial metabolism, is able to contribute to the generation of procarcinogenic toxic metabolites; increased extraction of energy and nutrient availability leading to metabolic dysregulation contributes to tumor initiation and progression. ${ }^{31-33}$ Among the above molecules, leptin is the most abundant adipokine. Since it was first cloned in 1994, ${ }^{34}$ this cytokine-like hormone, controlling adipocyte mass and energy balance by binding to the leptin receptor $(\mathrm{Ob}-\mathrm{R})$, has been the subject of intensive studies in cancer development.

Hepatocellular carcinoma (HCC) is the most typical liver cancer. Approximately three-quarters of total liver cancer worldwide are associated with HCC, which is the major histological subtype of liver cancer burden worldwide, and complicating cirrhosis due to chronic viral infection or toxic injury remains the third leading cause of cancer death in the world. HCC is increasingly diagnosed among individuals with obesity and related disorders. A systematic review and meta-analysis, along with other evidences, linked obesity to increased risk of common and less common malignancies, such as HCC. ${ }^{35}$ A number of epidemiological studies have reported that overweight and/or obesity are associated with a greater risk of HCC compared to the general population. ${ }^{36-39}$ A significant increase in serum leptin levels and a positive correlation between the serum levels of leptin and $\alpha$-fetoprotein in cirrhotic HCC group were also observed in HCC patients. ${ }^{40}$ The serum leptin levels were also found to be considerably higher in patients with HCC than in normal healthy controls in another study. ${ }^{41}$

In light of the increasingly reported role of leptin in several types of cancer, ${ }^{42-47}$ this review is focused on the updated knowledge on the oncogenic role of leptin signaling in the occurrence and development of $\mathrm{HCC}$, clinical significance, and development of specific drug targets in HCC. Additionally, leptin-induced angiogenic ability and molecular mechanisms in HCC cells are also discussed. The stringent binding affinity of leptin/Ob-R, the overexpression of leptin/ $\mathrm{Ob}-\mathrm{R}$, and its targets in cancer cells make leptin a unique drug target for the prevention and treatment of HCC, particularly in obese patients.

\section{Cellular and molecular structure and function of leptin and the leptin receptor}

Leptin, coded by the LEP gene, is a small, 167-amino acid, nonglycosylated protein. The name of "leptin" is derived from the Greek word "leptos," which means "thin". The biological function of leptin in energy homeostasis was determined by normalization of hyperphagy and obese phenotypes using recombinant leptin administration in rodents and humans. ${ }^{48,49}$ Leptin also plays critical roles in the regulation of immune response, growth, reproduction, glucose homeostasis, and angiogenesis. ${ }^{50-53}$ The $\mathrm{N}$-terminal region (94 amino acids) in leptin protein is essential for both its biological and receptor binding activities. ${ }^{54}$ The binding of leptin to $\mathrm{Ob}-\mathrm{R}$ is capable of inducing the extracellular domains of $\mathrm{Ob}-\mathrm{R}$ to form a homodimer, which constitutes the functional unit responsible for leptin-mediated signals.

$\mathrm{Ob}-\mathrm{R}$ belongs to a member of the class I cytokine receptor superfamily. ${ }^{55}$ This superfamily of receptors needs auxiliary kinases for activation because they lack autophosphorylation capabilities. So far, six leptin receptor isoforms generated by mRNA alternative splicing have been discovered ${ }^{56}$ : shorter isoforms with less biological activity (OB-RS) and the long isoform (OB-RL or OB-Rb) with full intracellular signaling capabilities. ${ }^{47,55}$ All Ob-R forms have the common large extracellular domain of Ob-R (816 amino acids). ${ }^{47}$ In contrast, all Ob-R forms have variable lengths of cytoplasmatic tail (300 amino acid residues). $.^{57,58} \mathrm{Ob}-\mathrm{R}$ binding to leptin induces its conformational changes that recruit Janus kinases (JAKs), which in turn phosphorylate $\mathrm{Ob}-\mathrm{R}$ and activate signal transducers and activators of transcription (STATs) ${ }^{47}$ In addition to the JAK2/STATs signaling pathway, leptin binding to $\mathrm{Ob}-\mathrm{R}$ also induces canonical (phosphoinositide 3-kinase $[\mathrm{PI}-3 \mathrm{~K}] /$ protein kinase B [Akt], mitogen-activated protein kinase [MAPK]/extracellular regulated kinase 1 and 2 [ERK $1 / 2]$ ), and noncanonical signaling pathways (AMPK, JNK, $\mathrm{PKC}$, and p38 MAPK) in diverse cell types. The long form $(\mathrm{Ob}-\mathrm{Rb})$ has a long intracellular domain which is essential for intracellular signal transduction. Only Ob-Rb in the leptin receptor isoforms contains an intact intracellular domain and has the ability to activate the intracellular JAK/STAT pathway on ligand binding. ${ }^{47,59}$ Importantly, leptin-mediated 
STAT3 (signal transducer and activator of transcription 3) signaling needs Tyr-1138 of Ob-Rb for its action. ${ }^{60-62}$ In addition, leptin-induced signals occur in normal peripheral tissues, but the high level of leptin in obesity could amplify leptin signaling, thereby finally inducing the development of obesity-associated cancers.

\section{Expression of leptin and Ob-R in human HCC}

Wang et $\mathrm{al}^{63}$ examined, using immunohistochemical staining, leptin expression in 36 cases of adjacent nontumorous liver tissues $(36 / 36,100 \%)$ with moderate $(++)$ to strong $(++)$ intensity and in $72.22 \%(26 / 36)$ of HCC with weaker $(+)$ intensity $(P<0.05)$. However, they suggested that further studies were needed to determine the inhibitory and/or activating role of leptin in the etiology, carcinogenesis, and progress of human HCC. ${ }^{63}$ In another report, ${ }^{64}$ high leptin expression was demonstrated in $60.3 \%$ of patients with HCC and was not correlated to Ki-67 expression, but it is significantly correlated to intratumor microvessel density (high vs low; 59.2 [standard deviation 3.2] vs 44.2 [19.5], $P=0.004)$. However, leptin expression was determined as a predictor for improved overall survival of patients with HCC (odds ratio [OR] 0.16; 95\% confidence interval $[\mathrm{CI}] 0.03-0.87 ; P=0.033$ ) using a multivariate Cox's proportional hazards model. Interestingly, high Ob-R expression was detected in $53 \%$ of HCC patients and was also significantly correlated to intratumor microvessel density (high vs low; 59.4 [3.2] vs 44.7 [3.7]; $P=0.004$ ). ${ }^{64}$ In addition, high $\mathrm{Ob}-\mathrm{R}$ expression was associated with a better overall survival ( $P=0.027$ ) using the Kaplan-Meier survival curve. ${ }^{64}$ Multivariate analysis also showed that $\mathrm{Ob}-\mathrm{R}$ expression was a significant determinant for $\mathrm{HCC}$ (OR $0.02,95 \% \mathrm{CI}$ $0.01-0.85 ; P=0.041) .{ }^{64}$ In a recent study ${ }^{65}$ the overexpression rate of leptin and Ob-R in 81 HCC patients was $56.8 \%$ and $35.8 \%$, respectively. Ob-R overexpression was significantly correlated to the tumor size and TNM stage $(P<0.05)$, but not to age, body mass index, $\alpha$-fetoprotein, hepatitis B surface antigen status, tumor grade, vascular invasion, or liver cirrhosis $(P \geq 0.05)$. Leptin overexpression showed no significant correlations to the above clinicopathological factors $(P \geq 0.05)$. In vitro, leptin and $\mathrm{Ob}-\mathrm{R}$ are simultaneously expressed in the HCC cell line HepG2. ${ }^{66}$ Leptin increased HepG2 cell proliferation in a concentration- and time-dependent manner. The effect of promotion of cell proliferation by leptin is due to the increment of DNA synthesis and enhancement of mitotic activity.

The results of the previous studies were inconsistent and contradictory. The existing conflicts among different studies might be due to the use of different tools or different stages of tumor tissues. Therefore, leptin may be involved in the occurrence and development of $\mathrm{HCC}$, and the specific role and mechanism needs further research.

\section{Interaction between leptin signaling and oncogenic pathways in HCC}

In the central nervous system, particularly in the hypothalamus, which is a site of high Ob-Rb mRNA expression, many of the effects are attributable to leptin. Alternative splicing and proteolytic cleavage events also produce a circulating extracellular domain of $\mathrm{Ob}-\mathrm{R}$, which may affect the stability of circulating leptin. ${ }^{47,51}$ The cell-membrane-bound short-form receptors may also have potentially important roles, including the endocytosis and transport of leptin across the blood-brain barrier. High levels of leptin in obese patients are not able to suppress feeding and decrease body weight (BW)/adiposity. The proposed mechanisms of leptin resistance include perturbations in developmental programming, alterations in cellular $\mathrm{Ob}-\mathrm{Rb}$ signaling, alterations in the transport of leptin across the blood-brain barrier, and others. ${ }^{67}$ In peripheral tissues, high levels of circulating leptin could also overregulate the signaling and expression of active $\mathrm{Ob}-\mathrm{R}$. These phenomena lead to the deregulation of leptin signaling, thereby significantly contributing to $\mathrm{HCC}$ progression through its crosstalk with multiple signaling pathways, as discussed in breast cancer ${ }^{47}$ or colorectal cancer. ${ }^{68}$

The PI-3K/Akt pathway, an assembly of membranelocalized complexes, plays a central role in a variety of multiple biological processes such as cell motility, proliferation, survival, and angiogenesis in tumor cells including HCC. ${ }^{69-72}$ The PI-3K/Akt pathway also plays a major role in tumor growth factor (TGF)- $\beta$-induced epithelial-mesenchymal transformation (EMT), notably through the regulation of translation and cell invasion during carcinogenesis. ${ }^{73,74}$ In addition, many of the transforming events in HCC are a result of the enhancement or deregulation of PI3-K/Akt pathway. ${ }^{72,75}$ A great number of studies have already established the central role of leptin-induced regulation of the $\mathrm{PI}-3 \mathrm{~K} / \mathrm{Akt}$ signaling pathway in several types of cancer including HCC (Figure 1). ${ }^{47,76-85}$

Mounting evidence has shown that the STAT3 is a frequent biochemical aberrant in the development, progression, and maintenance of cancer cells. ${ }^{86,87}$ STAT3 regulates a variety of genes involved in the regulation of critical functions, including immune responses, cell proliferation, differentiation, angiogenesis, apoptosis, and metastasis. STAT3 can function either as an oncoprotein or a tumor suppressor depending on the specific genetic background or in different 


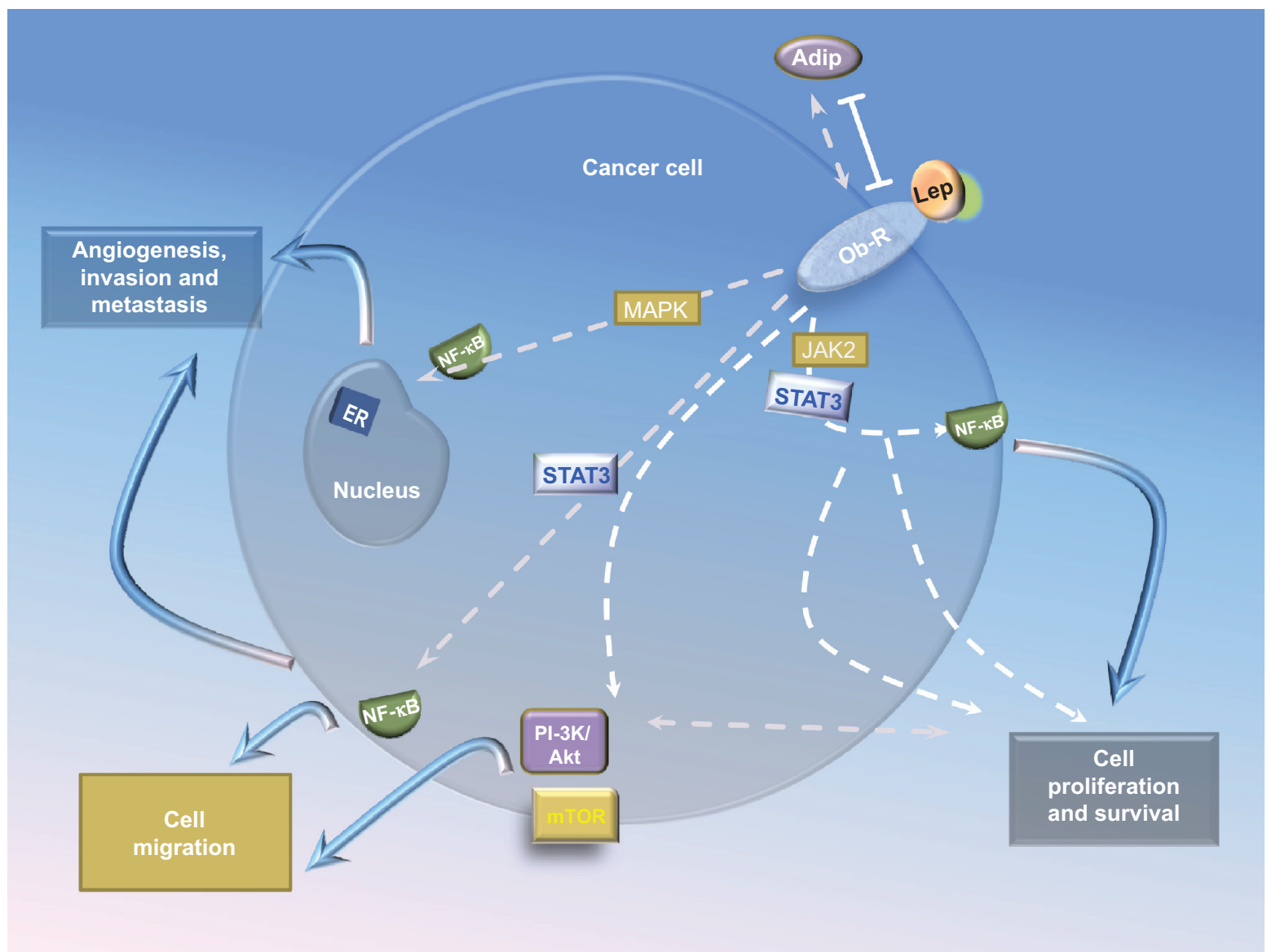

Figure I Crosstalk between leptin signaling and signaling pathways in HCC.

Notes: Leptin binding to the receptor Ob-R in HCC cells activates canonical (JAK2/STAT, MAPK, and PI-3K) signaling pathways. Leptin-induced JAK2/STAT3, MAPK, PI-3K/ mTOR, p38, and JNK signaling. PI-3K/Akt induces phosphorylation of mTOR. MAPK activation plays an important role in activating ERK I/2, p38, and JNK, which in turn induce NF- $\mathrm{KB}$ activation. Levels of proinflammatory/pro-angiogenic molecules can also be induced by leptin signaling pathways. Solid and dashed arrows indicate the main and alternative mechanisms of leptin actions.

Abbreviations: HCC, hepatocellular carcinoma; JAK2, Janus kinase 2; MAPK, mitogen-activated protein kinase; PI-3K, phosphoinositide 3-kinase; mTOR, mammalian target of rapamycin; Akt, protein kinase B; ERK I/2, extracellular regulated kinase I and 2; NF- $\mathrm{B}$, nuclear factor kappa-light-chain-enhancer of activated B cells; STAT, signal transducer and activator of transcription; Adip, adipose; Lep, leptin; ER, estrogen receptor.

contexts of cancer biology.$^{88}$ However, for many tumors, increased levels of activated STAT3 have been associated with worsened prognosis, indicating that STAT3 could be an attractive molecular target for the development of novel malignancy therapeutics. ${ }^{89,90}$

The STAT3 pathway mediates leptin actions on food intake, weight gain, glucose metabolism, and neuroendocrine function, but does not influence fertility and glycemic control. ${ }^{91}$ In malignant cells, the STAT3 pathway is involved in leptin actions in cell migration, ${ }^{85,92}$ proliferation, ${ }^{93-98}$ and anti-apoptosis. ${ }^{82,99,100}$ Leptin-STAT3 regulates the genes cyclooxygenase (COX)-2, ${ }^{83}$ cyclin D1 (kinase and regulator of cell cycle D1), ${ }^{93,95}$ human telomerase reverse transcriptase ( hTERT),${ }^{101}$ VEGF,${ }^{102,103}$ leptin,,${ }^{102}$ and survivin. ${ }^{104}$ STAT3 could also regulate nuclear factor kappa-light-chain-enhancer of activated B cells, ${ }^{105,106}$ IL-1, Notch, ${ }^{107,108}$ canonical WNT, ${ }^{109,110}$ and VEGFR-2, ${ }^{107,108}$ and thereby regulate tumor angiogenesis.
Leptin could crosstalk with signaling pathways which are involved in the pathogenesis of nonalcoholic fatty liver disease, which is a risk disease of HCC. ${ }^{111-113}$ Leptin is able to contribute to the development of insulin resistance, steatosis, proinflammation, and liver fibrosis. ${ }^{46,114}$ Leptin injections have been shown to result in the increased expression of procollagen-I, TGF- $\beta 1$, and smooth muscle actin which is a marker of activated hepatic stellate cells, and eventually to increased liver fibrosis. ${ }^{115}$

Leptin could also crosstalk with signaling pathways which involve in the development of fibrosis. Aleffi et al identified the effect of leptin on fibrogenic cells is the induction of vascular endothelial growth factor (VEGF) via oxygenindependent activation of hypoxia-inducible factor $1 \mathrm{a}$, which is a master switch of the angiogenic response. ${ }^{116}$ Their results strongly suggest the fibrogenic role of leptin in the liver. 


\section{Therapeutic potential for leptin/ Ob-R signaling molecules}

Evidence ever more strongly implicates that leptin/Ob-R signaling is correlated to many cancer types and point toward new drug targets. Leptin binds only to Ob-R. Moreover, the extracellular activation of $\mathrm{Ob}-\mathrm{R}$ is obtained only upon leptin binding to its extracellular region. ${ }^{47}$ Interestingly, this family of receptors is capable of binding only to leptin or leptin-modified peptides, indicating the potential use of leptin antagonists and/ or other inhibitors in blocking Ob-R signals. ${ }^{47,117}$

Previous studies have shown that blocking of leptin signaling could cause decreased growth and development of mammary tumors derived from mice and humans. ${ }^{118,119}$ Tumor growth and the expression of VEGF-A/VEGFR-2 were markedly reduced in orthotopic mouse models using a pegylated leptin peptide receptor antagonist (PEGLPrA2). ${ }^{118,119}$ The BW or appetite of a large number of normal lean (male and female) CD-1 and BALB/c mice did not change during a several months of using PEG-LPrA2. Surmacz's group reported similar results in the same orthotropic xenograft model using a different leptin antagonist (Allo-aca). ${ }^{120}$ Allo-aca induced 6\%-10\% BW increase, but it significantly extended the mouse survival time for 1-2 weeks and did not show systemic toxicity when tested for toxicity effects in normal CD-1 mice. ${ }^{120}$ Recently, the same group tested a number of Allo-aca analogs. d-Ser was a peptidominetic and distributed only in the periphery of experimental animals. This novel peptide d-Ser may serve as a prototype to develop new therapeutics because it significantly inhibited leptin-dependent proliferation of Ob-R-positive cancer cells in vitro at $1 \mathrm{nM}$ concentration without exhibiting any partial agonistic activity. ${ }^{121}$ The above results indicate that inhibition of leptin signaling by leptin antagonists may serve as a novel adjuvant for the treatment of HCC.

Several groups have developed antibodies targeting leptin signaling. Zabeau et al produced and evaluated a number of neutralizing nanobodies targeting Ob-R. ${ }^{122}$ Three classes of neutralizing nanobodies targeting different $\mathrm{Ob}-\mathrm{R}$ subdomains, ie, the Ig-like and fibronectin type III domains and cytokine receptor homology 2, were identified. Among them, only nanobodies directed against the cytokine receptor homology 2 domain inhibited leptin binding. Ross and Strasburger's groups developed monoclonal antibodies (mAbs) against human Ob-R and verified their antagonistic activity using an LEP-signaling bioassay. ${ }^{123,124} 9 \mathrm{~F} 8$, the most promising $\mathrm{mAb}$ showed dose-dependent antagonist activity using the LEP bioassay. However, all the above-mentioned antibodies have not been used in cancer therapy.
In summary, although there have already been compounds or antibodies targeting leptin/Ob-R that showed significant in vitro or in vivo anticancer effect, they have not been utilized in clinical settings. The major reason might be the low efficiency and specificity of some compounds or antibodies. In addition, the side effects of these drugs are not completely known and require further studies.

\section{Conclusion}

Obesity-associated inflammatory, metabolic, and endocrine mediators are suspected to play a role in tumorigenesis. Body fat and adipocyte size are clearly correlated to high leptin levels in obesity and in overweight individuals or populations. High leptin level is a hallmark of obesity, which has been correlated to the incidence and progression of several malignancies including HCC. In vitro studies have clearly demonstrated the role of leptin in HCC proliferation, migration, and angiogenesis. In addition, leptin signaling and its crosstalks with many signaling pathways, such as $\mathrm{PI}-3 \mathrm{~K} / \mathrm{Akt}$ and STAT3, play critical roles in HCC cell growth, invasion, angiogenesis, and metastasis. There are still a number of gaps to fill in the field of leptin signaling in HCC, especially further identification of the molecular mechanisms of leptinsignaling-mediated regulation of HCC. There are conflicting data concerning the correlation between tissue leptin level and HCC risk. Although several groups have developed antibodies targeting leptin signaling, all these antibodies have not been used in cancer therapy. Novel opportunities could emerge from the discovery of leptin crosstalk with other oncogenic pathways, inflammatory and angiogenic cytokines, and their links to obesity-related cancers.

\section{Acknowledgments}

This study was supported by the National Natural Science Foundation of China (No 81272420), the Scientific and Technological Development Projects in Shandong Province of China (No 2011GSF11838), Shandong Province Natural Science Foundation (No ZR2012HM085), and the Scientific and Technological Development Projects of Jinan City (No 201202039).

\section{Disclosure}

The authors declare no conflicts of interest in this work.

\section{References}

1. WHO. World Health Organization Fact Sheet for World Wide Prevalence of Obesity; 2006. Available from: http://www.who.int/mediacentre/ factsheets/fs311/en/. Accessed November 3, 2014.

2. James WP. International association for the study of obesity and China. Obes Rev. 2008;9(suppl 1):2-3 
3. Bibiloni MD, Pons A, Tur JA. Prevalence of overweight and obesity in adolescents: a systematic review. ISRN Obes. 2013;2013:392747.

4. De Pergola G, Silvestris F. Obesity as a major risk factor for cancer.JObes. 2013;2013:291546.

5. Baskin ML, Ard J, Franklin F, Allison DB. Prevalence of obesity in the United States. Obes Rev. 2005;6:5-7.

6. Ogden CL, Carroll MD, Curtin LR, McDowell MA, Tabak CJ, Flegal KM. Prevalence of overweight and obesity in the United States, 1999-2004. JAMA. 2006;295:1549-1555.

7. Huxley R, Mendis S, Zheleznyakov E, Reddy S, Chan J. Body mass index, waist circumference and waist:hip ratio as predictors of cardiovascular risk - a review of the literature. Eur J Clin Nutr. 2010; 64:16-22.

8. Cote AT, Harris KC, Panagiotopoulos C, Sandor GG, Devlin AM. Childhood obesity and cardiovascular dysfunction. J Am Coll Cardiol. 2013;62:1309-1319.

9. Kramer H, Dugas L, Shoham D. Obesity as an effect modifier of the risk of death in chronic kidney disease. Nephrol Dial Transplant. 2013;28(suppl 4):iv65-iv72.

10. de Vries AP, Ruggenenti P, Ruan XZ, et al; ERA-EDTA Working Group Diabesity. Fatty kidney: emerging role of ectopic lipid in obesity-related renal disease. Lancet Diabetes Endocrinol. 2014; 2:417-426.

11. Hall ME, do Carmo JM, da Silva AA, Juncos LA, Wang Z, Hall JE. Obesity, hypertension, and chronic kidney disease. Int $J$ Nephrol Renovasc Dis. 2014;7:75-88.

12. Franssen R, Monajemi H, Stroes ES, Kastelein JJ. Obesity and dyslipidemia. Endocrinol Metab Clin North Am. 2008;37:623-633, viii.

13. Kotsis V, Stabouli S, Papakatsika S, Rizos Z, Parati G. Mechanisms of obesity-induced hypertension. Hypertens Res. 2010;33:386-393.

14. DeMarco VG, Aroor AR, Sowers JR. The pathophysiology of hypertension in patients with obesity. Nat Rev Endocrinol. 2014; 10:364-376.

15. Cohen JC, Horton JD, Hobbs HH. Human fatty liver disease: old questions and new insights. Science. 2011;332:1519-1523.

16. Hui E, Xu A, Bo Yang H, Lam KS. Obesity as the common soil of nonalcoholic fatty liver disease and diabetes: role of adipokines. J Diabetes Investig. 2013;4:413-425.

17. Jung UJ, Choi MS. Obesity and its metabolic complications: the role of adipokines and the relationship between obesity, inflammation, insulin resistance, dyslipidemia and nonalcoholic fatty liver disease. Int $\mathrm{J} \mathrm{Mol}$ Sci. 2014;15:6184-6223.

18. Travers ME, McCarthy MI. Type 2 diabetes and obesity: genomics and the clinic. Hum Genet. 2011;130:41-58.

19. Basen-Engquist K, Chang M. Obesity and cancer risk: recent review and evidence. Curr Oncol Rep. 2011;13:71-76.

20. Paz-Filho G, Lim EL, Wong ML, Licinio J. Associations between adipokines and obesity-related cancer. Front Biosci. 2011;16: $1634-1650$

21. Lashinger LM, Ford NA, Hursting SD. Interacting inflammatory and growth factor signals underlie the obesity-cancer link. $J$ Nutr. 2014;144:109-113.

22. Teucher B, Rohrmann S, Kaaks R. Obesity: focus on all-cause mortality and cancer. Maturitas. 2010;65:112-116.

23. Wolin KY, Carson K, Colditz GA. Obesity and cancer. Oncologist. 2010;15:556-565.

24. Han G, Zhao W, Wang L, et al. Leptin enhances the invasive ability of glioma stem-like cells depending on leptin receptor expression. Brain Res. 2014;1543:1-8.

25. Colditz GA, Wolin KY, Gehlert S. Applying what we know to accelerate cancer prevention. Sci Transl Med. 2012;4:127rv4.

26. Prieto-Hontoria PL, Perez-Matute P, Fernandez-Galilea M, Bustos M, Martinez JA, Moreno-Aliaga MJ. Role of obesity-associated dysfunctional adipose tissue in cancer: a molecular nutrition approach. Biochim Biophys Acta. 2011;1807:664-678.

27. Zhang Y, Bellows CF, Kolonin MG. Adipose tissue-derived progenitor cells and cancer. World J Stem Cells. 2010;2:103-113.
28. Kwaan HC, McMahon B. The role of plasminogen-plasmin system in cancer. Cancer Treat Res. 2009;148:43-66.

29. Khan S, Shukla S, Sinha S, Meeran SM. Role of adipokines and cytokines in obesity-associated breast cancer: therapeutic targets. Cytokine Growth Factor Rev. 2013;24(6):503-513.

30. Riondino S, Roselli M, Palmirotta R, Della-Morte D, Ferroni P, Guadagni F. Obesity and colorectal cancer: role of adipokines in tumor initiation and progression. World J Gastroenterol. 2014;20: 5177-5190.

31. Rogers CJ, Prabhu KS, Vijay-Kumar M. The microbiome and obesity-an established risk for certain types of cancer. Cancer J. 2014; $20: 176-180$

32. von Scholten BJ, Andresen EN, Sorensen TI, Jess T. Aetiological factors behind adipose tissue inflammation: an unexplored research area. Public Health Nutr. 2013;16:27-35.

33. Russell WR, Duncan SH, Flint HJ. The gut microbial metabolome: modulation of cancer risk in obese individuals. Proc Nutr Soc. 2013; $72: 178-188$

34. Zhang Y, Proenca R, Maffei M, Barone M, Leopold L, Friedman JM. Positional cloning of the mouse obese gene and its human homologue. Nature. 1994;372:425-432.

35. Renehan AG, Tyson M, Egger M, Heller RF, Zwahlen M. Body-mass index and incidence of cancer: a systematic review and meta-analysis of prospective observational studies. Lancet. 2008;371:569-578.

36. Polesel J, Zucchetto A, Montella M, et al. The impact of obesity and diabetes mellitus on the risk of hepatocellular carcinoma. Ann Oncol. 2009;20:353-357.

37. Calle EE, Rodriguez C, Walker-Thurmond K, Thun MJ. Overweight, obesity, and mortality from cancer in a prospectively studied cohort of U.S. adults. $N$ Engl J Med. 2003;348:1625-1638.

38. Bianchini F, Kaaks R, Vainio H. Overweight, obesity, and cancer risk. Lancet Oncol. 2002;3:565-574.

39. Larsson SC, Wolk A. Overweight, obesity and risk of liver cancer: a meta-analysis of cohort studies. Br J Cancer. 2007;97:1005-1008.

40. Sadik NA, Ahmed A, Ahmed S. The significance of serum levels of adiponectin, leptin, and hyaluronic acid in hepatocellular carcinoma of cirrhotic and noncirrhotic patients. Hum Exp Toxicol. 2012;31: 311-321.

41. Wang YY, Lin SY. Leptin in relation to hepatocellular carcinoma in patients with liver cirrhosis. Horm Res. 2003;60:185-190.

42. Garofalo C, Surmacz E. Leptin and cancer. J Cell Physiol. 2006;207:12-22.

43. Jarde T, Perrier S, Vasson MP, Caldefie-Chezet F. Molecular mechanisms of leptin and adiponectin in breast cancer. Eur J Cancer. 2011;47:33-43.

44. Ray A, Cleary MP. Leptin as a potential therapeutic target for breast cancer prevention and treatment. Expert Opin Ther Targets. 2010;14:443-451

45. Ribeiro R, Lopes C, Medeiros R. Leptin and prostate: implications for cancer prevention - overview of genetics and molecular interactions. Eur J Cancer Prev. 2004;13:359-368.

46. Wang SN, Lee KT, Ker CG. Leptin in hepatocellular carcinoma. World J Gastroenterol. 2010;16:5801-5809.

47. Guo S, Liu M, Wang G, Torroella-Kouri M, Gonzalez-Perez RR. Oncogenic role and therapeutic target of leptin signaling in breast cancer and cancer stem cells. Biochim Biophys Acta. 2012;1825:207-222.

48. Farooqi IS, Jebb SA, Langmack G, et al. Effects of recombinant leptin therapy in a child with congenital leptin deficiency. $N$ Engl J Med. 1999;341:879-884.

49. Halaas JL, Gajiwala KS, Maffei M, et al. Weight-reducing effects of the plasma protein encoded by the obese gene. Science. 1995;269:543-546.

50. Leinninger GM. Location, location, location: the CNS sites of leptin action dictate its regulation of homeostatic and hedonic pathways. Int J Obes (Lond). 2009;33(supp1 2):S14-S17.

51. Myers MG Jr, Munzberg H, Leinninger GM, Leshan RL. The geometry of leptin action in the brain: more complicated than a simple ARC. Cell Metab. 2009;9:117-123. 
52. Robertson SA, Leinninger GM, Myers MG Jr. Molecular and neural mediators of leptin action. Physiol Behav. 2008;94:637-642.

53. Ashwin PJ, Dilipbhai PJ. Leptin and the cardiovascular system: a review. Recent Pat Cardiovasc Drug Discov. 2007;2:100-109.

54. Imagawa K, Numata Y, Katsuura G, et al. Structure-function studies of human leptin. J Biol Chem. 1998;273:35245-35249.

55. Fruhbeck G. Intracellular signalling pathways activated by leptin. Biochem J. 2006;393:7-20.

56. Friedman J. Leptin, leptin receptors, and the control of body weight. In: Blum WF, Kiess W, Rascher W, editors. Leptin - The Voice of Adipose Tissue. Heidelberg: JA Barth Verlag; 1997:3-22.

57. Tartaglia LA, Dembski M, Weng X, et al. Identification and expression cloning of a leptin receptor, OB-R. Cell. 1995;83:1263-1271.

58. Bazan JF. Structural design and molecular evolution of a cytokine receptor superfamily. Proc Natl Acad Sci U S A. 1990;87: 6934-6938.

59. Tartaglia LA. The leptin receptor. J Biol Chem. 1997;272: 6093-6096.

60. Banks AS, Davis SM, Bates SH, Myers MG Jr. Activation of downstream signals by the long form of the leptin receptor. J Biol Chem. 2000;275:14563-14572.

61. Bjorbaek C, Uotani S, da Silva B, Flier JS. Divergent signaling capacities of the long and short isoforms of the leptin receptor. J Biol Chem. 1997;272:32686-32695.

62. Stahl N, Farruggella TJ, Boulton TG, Zhong Z, Darnell JE Jr, Yancopoulos GD. Choice of STATs and other substrates specified by modular tyrosine-based motifs in cytokine receptors. Science. 1995;267:1349-1353.

63. Wang XJ, Yuan SL, Lu Q, et al. Potential involvement of leptin in carcinogenesis of hepatocellular carcinoma. World J Gastroenterol. 2004;10:2478-2481.

64. Wang SN, Yeh YT, Yang SF, Chai CY, Lee KT. Potential role of leptin expression in hepatocellular carcinoma. J Clin Pathol. 2006;59:930-934.

65. Chen L, Shi Y, Jiang CY, Sun Q, Wang LX, Dai GH. [Expression of leptin and leptin receptor in hepatocellular carcinoma and the clinicopathological significance]. Nan Fang Yi Ke Da Xue Xиe Bao. 2011; 31:830-833.

66. Zhou J, Lei W, Shen L, Luo HS, Shen ZX. Primary study of leptin and human hepatocellular carcinoma in vitro. World J Gastroenterol. 2008;14:2900-2904.

67. Myers MG, Cowley MA, Munzberg H. Mechanisms of leptin action and leptin resistance. Annu Rev Physiol. 2008;70:537-556.

68. Zhou W, Tian Y, Gong H, Guo S, Luo C. Oncogenic role and therapeutic target of leptin signaling in colorectal cancer. Expert Opin Ther Targets. 2014;19:1-11.

69. Steelman LS, Stadelman KM, Chappell WH, et al. Akt as a therapeutic target in cancer. Expert Opin Ther Targets. 2008;12:1139-1165.

70. Wickenden JA, Watson CJ. Key signalling nodes in mammary gland development and cancer. Signalling downstream of PI3 kinase in mammary epithelium: a play in 3 Akts. Breast Cancer Res. 2010; 12:202.

71. Agarwal E, Brattain MG, Chowdhury S. Cell survival and metastasis regulation by Akt signaling in colorectal cancer. Cell Signal. 2013;25:1711-1719.

72. Zhou Q, Lui VW, Yeo W. Targeting the PI3K/Akt/mTOR pathway in hepatocellular carcinoma. Future Oncol. 2011;7:1149-1167.

73. Sabbah M, Emami S, Redeuilh G, et al. Molecular signature and therapeutic perspective of the epithelial-to-mesenchymal transitions in epithelial cancers. Drug Resist Updat. 2008;11:123-151.

74. Lamouille S, Derynck R. Emergence of the phosphoinositide 3-kinaseAkt-mammalian target of rapamycin axis in transforming growth factor-beta-induced epithelial-mesenchymal transition. Cells Tissues Organs. 2011;193:8-22.

75. Fu Z, Ren L, Wei H, et al. Effects of Tyroserleutide on phosphatidylinositol 3'-kinase/AKT pathway in human hepatocellular carcinoma cell. J Drug Target. 2014;22:146-155.
76. Cheng SP, Yin PH, Hsu YC, et al. Leptin enhances migration of human papillary thyroid cancer cells through the PI3K/AKT and MEK/ERK signaling pathways. Oncol Rep. 2011;26:1265-1271.

77. Uddin S, Bu R, Ahmed M, et al. Leptin receptor expression and its association with PI3K/AKT signaling pathway in diffuse large B-cell lymphoma. Leuk Lymphoma. 2010;51:1305-1314.

78. Uddin S, Bavi P, Siraj AK, et al. Leptin-R and its association with PI3K/AKT signaling pathway in papillary thyroid carcinoma. Endocr Relat Cancer. 2010;17:191-202.

79. Riolfi M, Ferla R, Del Valle L, et al. Leptin and its receptor are overexpressed in brain tumors and correlate with the degree of malignancy. Brain Pathol. 2010;20:481-489.

80. Uddin S, Bu R, Ahmed M, et al. Overexpression of leptin receptor predicts an unfavorable outcome in Middle Eastern ovarian cancer. Mol Cancer. 2009;8:74.

81. Uddin S, Bavi PP, Hussain AR, et al. Leptin receptor expression in Middle Eastern colorectal cancer and its potential clinical implication. Carcinogenesis. 2009;30:1832-1840.

82. Shen Y, Wang Q, Zhao Q, Zhou J. Leptin promotes the immune escape of lung cancer by inducing proinflammatory cytokines and resistance to apoptosis. Mol Med Rep. 2009;2:295-299.

83. Gao J, Tian J, Lv Y, et al. Leptin induces functional activation of cyclooxygenase-2 through JAK2/STAT3, MAPK/ERK, and PI3K/ AKT pathways in human endometrial cancer cells. Cancer Sci. 2009;100:389-395.

84. Miyazaki T, Bub JD, Iwamoto Y. c-Jun NH(2)-terminal kinase mediates leptin-stimulated androgen-independent prostate cancer cell proliferation via signal transducer and activator of transcription 3 and Akt. Biochim Biophys Acta. 2008;1782:593-604.

85. Saxena NK, Sharma D, Ding X, et al. Concomitant activation of the JAK/STAT, PI3K/AKT, and ERK signaling is involved in leptin-mediated promotion of invasion and migration of hepatocellular carcinoma cells. Cancer Res. 2007;67:2497-2507.

86. Fletcher S, Drewry JA, Shahani VM, Page BD, Gunning PT. Molecular disruption of oncogenic signal transducer and activator of transcription 3 (STAT3) protein. Biochem Cell Biol. 2009;87:825-833.

87. Masciocchi D, Gelain A, Villa S, Meneghetti F, Barlocco D. Signal transducer and activator of transcription 3 (STAT3): a promising target for anticancer therapy. Future Med Chem. 2011;3:567-597.

88. Zhang HF, Lai R. STAT3 in cancer-friend or foe? Cancers (Basel). 2014;6:1408-1440.

89. Mankan AK, Greten FR. Inhibiting signal transducer and activator of transcription 3: rationality and rationale design of inhibitors. Expert Opin Investig Drugs. 2011;20:1263-1275.

90. Zhao M, Jiang B, Gao FH. Small molecule inhibitors of STAT3 for cancer therapy. Curr Med Chem. 2011;18(26):4012-4018.

91. Bates SH, Kulkarni RN, Seifert M, Myers MG Jr. Roles for leptin receptor/STAT3-dependent and -independent signals in the regulation of glucose homeostasis. Cell Metab. 2005;1:169-178.

92. Ratke J, Entschladen F, Niggemann B, Zanker KS, Lang K. Leptin stimulates the migration of colon carcinoma cells by multiple signaling pathways. Endocr Relat Cancer. 2010;17:179-189.

93. Catalano S, Giordano C, Rizza P, et al. Evidence that leptin through STAT and CREB signaling enhances cyclin D1 expression and promotes human endometrial cancer proliferation. J Cell Physiol. 2009;218:490-500.

94. Li L, Gao Y, Zhang LL, He DL. Concomitant activation of the JAK/ STAT3 and ERK1/2 signaling is involved in leptin-mediated proliferation of renal cell carcinoma Caki-2 cells. Cancer Biol Ther. 2008; 7:1787-1792.

95. Saxena NK, Vertino PM, Anania FA, Sharma D. Leptin-induced growth stimulation of breast cancer cells involves recruitment of histone acetyltransferases and mediator complex to CYCLIN D1 promoter via activation of Stat3. J Biol Chem. 2007;282:13316-13325.

96. Pai R, Lin C, Tran T, Tarnawski A. Leptin activates STAT and ERK2 pathways and induces gastric cancer cell proliferation. Biochem Biophys Res Commun. 2005;331:984-992. 
97. Yin N, Wang D, Zhang H, et al. Molecular mechanisms involved in the growth stimulation of breast cancer cells by leptin. Cancer Res. 2004;64:5870-5875.

98. Dieudonne MN, Machinal-Quelin F, Serazin-Leroy V, Leneveu MC, Pecquery R, Giudicelli Y. Leptin mediates a proliferative response in human MCF7 breast cancer cells. Biochem Biophys Res Commun. 2002;293:622-628.

99. Ogunwobi OO, Beales IL. The anti-apoptotic and growth stimulatory actions of leptin in human colon cancer cells involves activation of JNK mitogen activated protein kinase, JAK2 and PI3 kinase/Akt. Int J Colorectal Dis. 2007;22:401-409.

100. Russo VC, Metaxas S, Kobayashi K, Harris M, Werther GA. Antiapoptotic effects of leptin in human neuroblastoma cells. Endocrinology. 2004;145:4103-4112.

101. Ren H, Zhao T, Wang X, et al. Leptin upregulates telomerase activity and transcription of human telomerase reverse transcriptase in MCF-7 breast cancer cells. Biochem Biophys Res Commun. 2010; 394:59-63.

102. Cascio S, Ferla R, D'Andrea A, et al. Expression of angiogenic regulators, VEGF and leptin, is regulated by the EGF/PI3K/STAT3 pathway in colorectal cancer cells. J Cell Physiol. 2009;221:189-194.

103. Gonzalez-Perez RR, Xu Y, Guo S, Watters A, Zhou W, Leibovich SJ. Leptin upregulates VEGF in breast cancer via canonic and noncanonical signalling pathways and NFkappaB/HIF-1alpha activation. Cell Signal. 2010;22:1350-1362.

104. Jiang H, Yu J, Guo H, Song H, Chen S. Upregulation of survivin by leptin/STAT3 signaling in MCF-7 cells. Biochem Biophys Res Commun. 2008;368:1-5.

105. Fan Y, Mao R, Yang J. NF-kappaB and STAT3 signaling pathways collaboratively link inflammation to cancer. Protein Cell. 2013;4:176-185.

106. He G, Karin M. NF-kappaB and STAT3 - key players in liver inflammation and cancer. Cell Res. 2011;21:159-168.

107. Guo S, Gonzalez-Perez RR. Notch, IL-1 and leptin crosstalk outcome (NILCO) is critical for leptin-induced proliferation, migration and VEGF/VEGFR-2 expression in breast cancer. PLoS One. 2011;6(6):e21467.

108. Zhou W, Guo S, Gonzalez-Perez RR. Leptin pro-angiogenic signature in breast cancer is linked to IL-1 signalling. $\mathrm{Br} J$ Cancer. 2011;104:128-137.

109. Ohba S, Lanigan TM, Roessler BJ. Leptin receptor JAK2/STAT3 signaling modulates expression of Frizzled receptors in articular chondrocytes. Osteoarthritis Cartilage. 2010;18:1620-1629.

110. Endo H, Hosono K, Uchiyama T, et al. Leptin acts as a growth factor for colorectal tumours at stages subsequent to tumour initiation in murine colon carcinogenesis. Gut. 2011;60:1363-1371.
111. Michelotti GA, Machado MV, Diehl AM. NAFLD, NASH and liver cancer. Nat Rev Gastroenterol Hepatol. 2013;10:656-665.

112. Duan XY, Zhang L, Fan JG, Qiao L. NAFLD leads to liver cancer: do we have sufficient evidence? Cancer Lett. 2014;345:230-234.

113. White DL, Kanwal F, El-Serag HB. Association between nonalcoholic fatty liver disease and risk for hepatocellular cancer, based on systematic review. Clin Gastroenterol Hepatol. 2012;10:1342. e2-e1359.e2.

114. Polyzos SA, Kountouras J, Zavos C, Deretzi G. The potential adverse role of leptin resistance in nonalcoholic fatty liver disease: a hypothesis based on critical review of the literature. J Clin Gastroenterol. 2011;45:50-54.

115. Ikejima K, Honda $\mathrm{H}$, Yoshikawa $\mathrm{M}$, et al. Leptin augments inflammatory and profibrogenic responses in the murine liver induced by hepatotoxic chemicals. Hepatology. 2001;34:288-297.

116. Aleffi S, Petrai I, Bertolani C, et al. Upregulation of proinflammatory and proangiogenic cytokines by leptin in human hepatic stellate cells. Hepatology. 2005;42:1339-1348.

117. Gonzalez RR, Leavis PC. A peptide derived from the human leptin molecule is a potent inhibitor of the leptin receptor function in rabbit endometrial cells. Endocrine. 2003;21:185-195.

118. Gonzalez RR, Cherfils S, Escobar M, et al. Leptin signaling promotes the growth of mammary tumors and increases the expression of vascular endothelial growth factor (VEGF) and its receptor type two (VEGF-R2). J Biol Chem. 2006;281:26320-26328.

119. Rene Gonzalez R, Watters A, Xu Y, et al. Leptin-signaling inhibition results in efficient anti-tumor activity in estrogen receptor positive or negative breast cancer. Breast Cancer Res. 2009;11:R36.

120. Otvos L Jr, Kovalszky I, Riolfi M, et al. Efficacy of a leptin receptor antagonist peptide in a mouse model of triple-negative breast cancer. Eur J Cancer. 2011;47:1578-1584.

121. Beccari S, Kovalszky I, Wade JD, Otvos L Jr, Surmacz E. Designer peptide antagonist of the leptin receptor with peripheral antineoplastic activity. Peptides. 2013;44:127-134.

122. Zabeau L, Verhee A, Catteeuw D, et al. Selection of non-competitive leptin antagonists using a random nanobody-based approach. Biochem J. 2012;441:425-434.

123. Fazeli M, Zarkesh-Esfahani $\mathrm{H}, \mathrm{Wu} \mathrm{Z}$, et al. Identification of a monoclonal antibody against the leptin receptor that acts as an antagonist and blocks human monocyte and T cell activation. J Immunol Methods. 2006;312:190-200.

124. Carpenter B, Hemsworth GR, Wu Z, et al. Structure of the human obesity receptor leptin-binding domain reveals the mechanism of leptin antagonism by a monoclonal antibody. Structure. 2012;20:487-497.
Drug Design, Development and Therapy

\section{Publish your work in this journal}

Drug Design, Development and Therapy is an international, peerreviewed open-access journal that spans the spectrum of drug design and development through to clinical applications. Clinical outcomes, patient safety, and programs for the development and effective, safe, and sustained use of medicines are a feature of the journal, which

\section{Dovepress}

has also been accepted for indexing on PubMed Central. The manuscript management system is completely online and includes a very quick and fair peer-review system, which is all easy to use. Visit http://www.dovepress.com/testimonials.php to read real quotes from published authors. 